УДК 378:373.3.011.3-051=111

\title{
THE RESULTS OF AN EXPERIMENTAL STUDY OF THE FORMATION OF THE AXIO-AKMEOLOGIC AND MOTIVATIONAL COMPONENT OF PEDAGOGICAL SKILL OF FUTURE TEACHERS OF ELEMENTARY SCHOOL
}

Telychko Natalia, Panteliychuk Vaselyna

\section{РЕЗУЛЬТАТИ ЕКСПЕРИМЕНТАЛЬНОГО ДОСЛДЖЕННЯ 3 ФОРМУВАННЯ АКСІО-АКМЕОЛОГІЧНО-МОТИВАЦІЙНОГО КОМПОНЕНТА ПЕДАГОГІЧНОЇ МАЙСТЕРНОСТІ МАЙБУТНІХ ВЧИТЕЛІВ ПОЧАТКОВИХ КЛАСІВ}

Теличко Н. В., Пантелійчук В.

The urgency of implementation of innovative approaches to the professional training of future primary teachers has been substantiated in the article. The aim of the research is to analyze the results of an axio-acmeologic and motivational component of pedagogical mastery of future teachers of elementary school.

The main task of the article is to summarize the results of an experimental study about the formation of the axio-acmeologic and motivational component of pedagogical mastery of future elementary school teachers.

The main stages of experimental research of formation their basic pedagogical mastery have been determined. The main indicators of the work done at every stage have been defined. The results of constating experiment actuality purposeful formation of the bases of pedagogical mastery of the future primary teachers have been indicated.

Keywords: motivation, students, future teachers of elementary school, experiment, pedagogical mastery, axio-acmeologic and motivational component of pedagogical mastery.

У статті аргументовано актуальність використання інноваційних підходів до професійної підготовки майбутніх учителів початкових класів і визначено основні етапи експериментального дослідження формування у них основ педагогічної майстерності. Відзначено основні показники проведеної роботи на кожному етапі. Зазначено результати констатувального етапу експерименту, що актуалізує иілеспрямоване формування основ педагогічної майстерності майбутніх учителів початкових класів.

Основним завданням написання статті $\epsilon$ узагальнення результатів експериментального дослідження 3 формування аксіо-акмеологічно-мотиваційного компонента педагогічної майстерності майбутніх учителів початкових класів.

На основі теоретико-методологічного аналізу наукової літератури визначено та обтрунтовано сутність аксіо-акмеологічної професійної мотивації, що спрямовується на формування аксіо-акмеологічно-мотиваційного компоненту педагогічної майстерності майбутніх учителів початкових класів. Критеріями ефективності формування аксіоакмеологічно-мотивачійного компоненту визначено професійні мотиви і иіннісні орієнтації до професійного становлення вчителя-майстра як вершини у майбутній фаховій діяльності.

3 метою аксіо-акмеологічної професійної мотивачії в процесі професійної підготовки майбутніх учителів початкових класів створювалося мотивачійно-аксіологічне середовище для усвідомлення студентами важливості та потреби професійного зростання. За всіма рівнями результативність формування аксіо-акмеологічно-мотиваційного компоненту педагогічної майстерності у майбутніх учителів початкових класів експериментальних груп була крамою. Доведено вірогідність отриманих результатів $i$ достовірність експериментального дослідження з використанням статистичних методів обробки даних педагогічного експерименту. Отже, мотивачія студентів до формування педагогічної майстерності визначає спрямованість майбутніх учителів до усвідомлення цінності і ијілей у професійному зростанні. 
Ключові слова: мотивація, студенти, майбутні вчителі початкових класів, експеримент, педагогічна майстерність, аксіо-акмеологічно-мотивачійний компонент педагогічної майстерності

The results of the theoretical analysis of the psychological aspects of motivation has suggested that the researchers understand the professional motivation of pedagogical activity as a qualitative characteristic of the teacher's personality, which originates from the motivation of choosing a profession as a necessary component of a professional orientation formation, in particular, at future teachers of elementary school [1, p. 45].

The main task of the article has been the synthesis of the results of experimental research of the formation of the axio-acmeologic and motivational component of pedagogical mastery of the future elementary school teachers.

Due to the purpose of acme-axiological professional motivation in the process of training the future teachers of elementary school, a motivational and axiological environment has been created to make students become aware of the importance and needs of professional growth. Through the use of questionnaires, surveys, participation of students of Mukachevo State University in the implementation of situational pedagogical tasks, the students' solution to the simulated professional and pedagogical situations in the developed "Training on the formation of pedagogical skill foundations ", the levels of this phenomenon formation in students of control and experimental groups at the stages of the input and final control have been established.

The determination of the final level of the formation of the axio-akmeologic and motivational component of pedagogical mastery of future teachers of elementary school has been established in the final classes on disciplines "Fundamentals of pedagogical skill". Using the methods of questioning and testing determined the level of knowledge and motives of mastering the basics of pedagogical skill, which had a value-critical importance for the professional growth of each student [2, p. 81].

In order to analyze the results of the experimental investigation, a comparison method of the input and final levels of the formation of the axio-acmeologic and motivational component of the pedagogical mastery of future teachers of the elementary school who have been trained in the control and experimental groups has been carried out have been applied (Table 1).

Table 1

Digital indicators of levels of the axio-acmeologic and motivational component of pedagogical mastery formation of the future elementary school teachers

\begin{tabular}{|c|c|c|c|c|c|c|c|c|c|c|c|c|}
\hline \multirow[t]{3}{*}{ Group } & \multirow{3}{*}{$\begin{array}{l}\text { Stage of } \\
\text { control }\end{array}$} & \multicolumn{10}{|c|}{$\begin{array}{l}\text { Levels of formation of the axio-acmeologic and motivational } \\
\text { component of pedagogical mastery of students }\end{array}$} & \multirow[t]{3}{*}{ AI } \\
\hline & & \multicolumn{2}{|c|}{ Creative } & \multicolumn{2}{|c|}{ High } & \multicolumn{2}{|c|}{ Average } & \multicolumn{2}{|c|}{ Satisfactory } & \multicolumn{2}{|c|}{ Low } & \\
\hline & & $\mathrm{N}$ & $\%$ & $\mathrm{~N}$ & $\%$ & $\mathrm{~N}$ & $\%$ & $\mathrm{~N}$ & $\%$ & $\mathrm{~N}$ & $\%$ & \\
\hline \multirow[t]{2}{*}{ CG } & $\begin{array}{l}\text { IC- } \\
126 \text { students }\end{array}$ & 12 & 9,52 & 26 & 20,63 & 52 & 41,27 & 32 & 25,40 & 4 & 3,17 & 3,06 \\
\hline & $\begin{array}{l}\text { CC- } \\
124 \text { students }\end{array}$ & 21 & 16,93 & 29 & 23,39 & 49 & 39,52 & 25 & 20,16 & 0 & 0 & 3,37 \\
\hline \multirow[t]{2}{*}{ EG } & $\begin{array}{l}\text { IC- } \\
125 \text { students }\end{array}$ & 11 & 8,80 & 27 & 21,60 & 51 & 40,80 & 33 & 26,40 & 3 & 2,40 & 3,08 \\
\hline & $\begin{array}{l}\text { CC- } \\
122 \text { students }\end{array}$ & 49 & 40,16 & 35 & 28,69 & 23 & 18,85 & 15 & 12,30 & 0 & 0 & 3,97 \\
\hline
\end{tabular}

Symbols:

CG - control groups; EG - experimental groups; N - number of students; AI - the average digital index of the formation of a certain component of pedagogical mastery of students, provided that each level has been designated in a 5-point assessment. 
The criterion for the conduction of mathematical calculations in order to prove the probability of the obtained results, it has been necessary to have each of the levels being identified by one digital index, but not in certain digital limits (for example, from 100 to 90 points). Therefore, each of the levels has been identified by one number in the five-point grade system. The indicators for each level have been given in the following limits:

- creative (active and forming) - 90-100 points with grade A (excellent) - 5 points;

- high (constructive and variational) - 82-89 points with an grade B (very good) - 4 points;

- average (professional and functional) - 75-81 points with grade C (good) - 3 points;

- satisfactory (limited and reproductive) level - 65-74 points with grade D (satisfactory) - 2 points;

- low (elemental) - 60-64 points with grade E (acceptable/sufficient) - 1 point.

The indicators of the formation of this component are: valuable awareness of the personal needs of professional growth, the manifestation of the desire for the formation of a master-teacher, a clear outline of professional vertices and the formation of motives for achieving excellence, the manifestation of creativity, mastery in pedagogical activity.

The analysis of Table 1 has made it possible to note that at all levels the effectiveness of the formation of the axiom-acmeologic and motivational component of pedagogical mastery in future teachers of elementary school, the experimental groups have been better. It also has been proved by the comparisons of the average digital indicators. Thus, in control groups these indicators have grown from 3,06 to 3,37 points (by 0,31 points), and in experimental groups - from 3,08 to 3,97 points (by 0,89 points), which is 0,58 points better than in control groups [4, p. 6].

The probability of the obtained results and the reliability of the experimental study have been proved with the use of statistical methods of pedagogical experiment data procession. For this purpose, the scientific approaches of researchers, which have determined the admissible least number of persons in the experimental group, have been taken into account. Thus, according to E. Stuullman it has been expedient to use the concept of a small sample in methodical experiments, according to which it has been sufficient for the comparison, having 24 people in experimental and control groups. If the quantity has been larger, the comparative data begin to repeat [5, p. 64].

The quantity of students in control groups (126-124 persons) and experimental groups (125122 people) has been quite sufficient to prove the probability of the results of our experimental investigation.

In order to test the hypothesis of the study by means of mathematical statistics, the comparison of dispersions with the help of the F-criterion has been used.

This value has been determined by the formula 1, substantiated by A. Kiverialg [3, p. 27]:

$$
F_{\text {emp }}={\frac{\sigma^{2}}{\sigma_{2}^{2}}}^{2}
$$

The main components of this formula are:

Femp-empirical value of the F-criterion (calculated from the experimental data) for control and experimental groups, the magnitude of which has been compared with the theoretical Fcriterion (Fkrit);

$\sigma_{1}^{2}-$ a digital index of greater dispersion; $\sigma_{2}^{2}-$ a digital index of less dispersion.

The value of dispersion has been calculated at the initial and final determination of the levels of formation of the basis of pedagogical mastery by the formula 2 :

$$
\sigma^{2}=\frac{\sum f\left(x_{i}-\bar{x}\right)^{2}}{N}
$$

$f-$ the quantity of students which have shown a certain level of formation of pedagogical mastery, that has a digital expression for mathematical calculations in a five-point system (creative 5 points, high -4 points, average -3 points, satisfactory -2 points and low -1 point) ; - these data have been presented in Table 1 and have been indicated in the column $\mathrm{N}$; 
index $(\mathrm{AI})$.

$\left(x_{i}-\bar{x}\right)-$ the difference between the digital values of each level and the value of the average

$\mathrm{N}$ - the total number of students in those categories of groups (control or experimental), where the dispersion has been calculated.

To verify the reliability of the obtained results, we have compared the calculated and determined indices of the empirical F-criterion in the control (Femp-CG) and experimental groups (Femp-EG) with the theoretical F-criterion (Fkrit), whose numerical values have been shown in the standard table by A. Kiverialg [3, p. 28].

The statistics has shown that if the number of degrees of freedom (the number of students in the group minus 1) is in the range from 24 to infinity and from 120 to infinity (in our investigation, this number corresponds to the number of students in control groups: $126-1=125$ at the stage of input control and 124-1 = 123 at the final control stage; in the experimental groups: $125-1=124$ at the input control stage and $122-1=121$ at the final control stage), the Fkrit value would be within the range of $1.6-1.0$, but closer to 1.6 than to 1.0 (as an indicator of an infinite number of investigations).

The comparative analysis of the empirical index of the F-criterion of control and experimental groups with defined limits Fkrit has shown that Femp-CG with a value of 1.02 is close to the quantity of infinite number of those who has been investigated, and Femp-EG with an index of 1.36 confirms the reliability of the results.

The motivation of students to form a pedagogical mastery has determined the orientation of future elementary school teachers to the realization of values and goals in professional growth. On the basis of theoretical and methodological analysis of scientific literature, the essence of axioacmeological professional motivation has been determined and substantiated. It is aimed at forming an axio-acmeologic and motivational component of pedagogical mastery of future elementary school teachers. Probability of the obtained results and reliability of experimental research with the use of statistical methods for processing pedagogical experiment data have been proved.

\section{References}

1. Kozachenko S. (2011), Cinnisno-smyslova sfera osobystosti majbutn`ogo vchytelya: analiz klyuchovyx ponyat [Value and semantic sphere of the future teacher personality: the analysis of key concepts]. Pedagogika ta psyxologiya. Pedagogy and Psychology, 589, pp. 74-81

2. Grynova V. M. Zolotuxina S. T., Balbenko S. Yu. (2006), Pedagogichna majsternist' uchytelya [Pedagogical skills of the teacher]. (Vol 2), Kh. : OVS

3. Kyveryalg A. A. (1980), Metody issledovaniya v professional'noj pedagogike [Methods of study in professional pedagogy], Tallin : Valgus

4. Telychk N. V. (2014), Teoretychni i metodychni zasady formuvannya osnov pedagogichnoyi majsternosti majbutnix uchyteliv pochatkovyx klasiv [Theoretical and methodical principles of forming the foundations of pedagogical mastery of future teachers of elementary school ], Doctor's thesis, Vinnycya

5. Shtulman E.A. (1988), SpecyfIka metodIcheskogo eksperimenta [Specificity of the methodical experiment]. Sov. Pedagogika. Soviet Pedagogy, 3, pp. 61-65 